УДК 631.452:631.445.4:631.8

\title{
ПАРАМЕТРЫ ИЗМЕНЕНИЯ ПОКАЗАТЕЛЕЙ ПЛОДОРОДИЯ ЧЕРНОЗЕМА ТИПИЧНОГО ПРИ МНОГОЛЕТНЕМ ИСПОЛЬЗОВАНИИ УДОБРЕНИЙ
}

\author{
БOEBA H.H., \\ кандидат сельскохозяйственных наук, старший научный сотрудник ФГБНУ Курский ФАНЦ, \\ тел. 8- 960-695-54-43; e-mail: nnboeva@gmail.com.
}

ДЕРИГЛАЗОВА Г.М., доктор сельскохозяйственных наук, ведущий научный сотрудник лаборатории «Агрохимии ГИС и АЭМ», ФГБНУ Курский ФАНЦ, e-mail: g_deriglazova@mail.ru.

Реферат. Согласно распоряжению Правительства РФ в 2012 г. принят закон № 297-р по эффективному использованию земельного фонда на 2012-2020 гг., в котором говорится об охране почв, как главного средства производства в сельском хозяйстве. Таким образом, особое место отводится рациональному использованию почвенных ресурсов при производстве на ней продукции растениеводства. Ресурсы почвы под действием человека и природных факторов постоянно находятся в процессе изменения своих качественных величин. Непропорциональность между эффективным и потенциальным плодородием возникает в результате стремления к постоянному повышению урожайности культур посредством нерационального внесения минеральных удобрений и почти полного отсутствия применения удобрений органических. В результате чего происходит постепенное снижение эффективного плодородия почвы. Качество почвы, под действием влияющих на неё факторов, не остается постоянным, а претерпевает изменения отдавая свои ресурсы и нуждается в их пополнении, т. к. в противном случае происходит её деградация и нарушение целой системы взаимосвязей в природе. В этой связи особо актуальны исследования и наблюдения за состоянием почвы и ее изменениями в процессе продолжительного использования минеральных, органических удобрений и их сочетаний при сельскохозяйственном производстве продуктов растениеводства.

Стационарные исследования за изменением плодородия чернозёма типичного от ежегодного внесения в течение трех ротаций различных видов удобрений позволили установить, что использование органоминеральной системы удобрений в зернопропашном севообороте содействует улучшению водопрочности почвенных агрегатов, и физико-химических свойств в целом, создает прогрессивный рост накопления различных форм фосфора в почве и его положительному балансу в севообороте.

Ключевые слова: типичный чернозем, севооборот, плодородие, почва, водопрочность, удобрения, фосфор, калий, степень подвижности элементов, баланс.

\section{PARAMETERS OF CHANGE IN FERTILITY INDICATORS OF CHERNOZEM TYPICAL WITH MANY YEARS OF FERTILIZER USE}

BOEVA N.N., candidate of Agricultural Sciences, Senior Researcher of the Kursk FAN Federal Research Institute, tel. 8-960-695-54-43; e-mail: nnboeva@gmail.com.

DERIGLAZOVA G.M., doctor of Agricultural Sciences, Leading Researcher of the Laboratory of Agrochemistry GIS and AEM, Kursk FANTS, e-mail: g_deriglazova@mail.ru.

Essay. According to the order of the Government of the Russian Federation, in 2012 a law No. 297-p was adopted on the effective use of the land fund for 2012-2020, which refers to the protection of the soil as the main means of production in agriculture. Thus, a special place is given to the rational use of soil resources in the production of plant products on it. Soil resources under the influence of man and natural factors are constantly in the process of changing their quality values. The disproportion between effective and potential fertility arises as a result of the desire to constantly increase the yield of crops through the irrational application of mineral fertilizers and the almost complete absence of the use of organic fertilizers. As a result, there is a gradual decrease in effective soil fertility. The quality of the soil, under the influence of the factors influencing it, does not remain constant, but undergoes changes giving up its resources and needs to be replenished, because otherwise it degrades and disrupts the whole system of interconnections in nature. In this regard, studies and observations of the state of the soil and its changes in the process of prolonged use of mineral, organic fertilizers and their combinations in the agricultural production of crop products are particularly relevant. 
Stationary studies of the change in chernozem fertility typical of different types of fertilizers applied annually during three rotations made it possible to establish that the use of an organomineral fertilizer system in grain cultivating crop rotation improves the water content of soil aggregates and the physicochemical properties as a whole, creates a progressive increase in the accumulation of various forms of phosphorus in soil and its positive balance in crop rotation.

Key words: typical black soil, crop rotation, fertility, soil, water resistance, fertilizer, phosphorus, potassium, degree of mobility of elements, balance.

Введение. Повышение устойчивости земледелия - одна из основных задач современности. Эта задача многогранная, включающая в себя хозяйственные, агротехнические, экологические мероприятия. Наиболее надежное средство повышение продуктивности возделываемых сельскохозяйственных культур является повышение плодородия почв и общей культуры земледелия.

В составе технологии возделывания полевых культур система удобрения занимает ведущее место, т.к. она оказывает большое влияние не только на их продуктивность, но что особенно важно на плодородие почвы. Разработками ученых показано, что доля вклада минеральных удобрений в формировании урожайности в ЦЧЗ варьирует от 20 до $80 \%[1,2,3]$.

Непропорциональность между эффективным и потенциальным плодородием возникает в результате стремления к бесконечному повышению урожайности культур посредством нерационального внесения минеральных удобрений и почти полного отсутствия применения удобрений органических. В результате чего происходит постепенное снижение эффективного плодородия почвы [4]. Под действием влияющих на неё факторов качество почвы не остается постоянным, а претерпевает изменения отдавая свои ресурсы в процессе возделывания культур и нуждается в их пополнении, т. к. в противном случае происходит её деградация и нарушение целой системы взаимосвязей в природе. В этой связи особо актуальны исследования и наблюдения за состоянием почвы и ее изменениями в процессе продолжительного использования минеральных, органических удобрений и их сочетаний при сельскохозяйственном производстве продуктов растениеводства.

Материал и методика исследования. Исследования проводились в стационарном опыте на территории КНИИ АПП в течение четырех ротаций четырехпольного зернопропашного севооборота. Объект исследования - типичный среднемощный среднегумусный чернозем с вскипанием на глубине 55-80 см. Пахотный слой стационарного участка имел следующие исходные данные:

объёмный вес $-0,97-1,14$ г $/ \mathrm{cm}^{2}$ с общей порозностью от 56 до $63 \%$ и мощностью гумусового горизонта от 80 до $100 \mathrm{~cm}$; параметры гумуса изменялись от 5,4 до 5,9 \%; гидролитическая кислотность колебалась от 1,5 до 3,0 мг-экв/100 г почвы, содержание подвижных форм фосфора и калия соответственно составляли 8-9 и 17-19 мг/100 г почвы.

Опыт заложен на водораздельном плато в зернопропашном севообороте с чередованием культур: - занятый пар, озимая пшеница, сахарная свекла, ячмень. Стационар в пространстве развернут на трех полях с ежегодным вхождением одним полем. Повторность вариантов четырехкратная, посевная площадь делянки - $175 \mathrm{~m}^{2}$, учетная - 100 $\mathrm{M}^{2}$. Минеральные и органические удобрения вносили осенью под зяблевую вспашку разовой дозой. Под каждую культуру севооборота вносили свою дозу минеральных удобрений (таблица 1).

Органические удобрения вносили один раз за ротацию севооборота под озимую пшеницу без минеральных удобрений и на фоне $\mathrm{N}_{60} \mathrm{P}_{60} \mathrm{~K}_{30}$. Bce агротехнические мероприятия проводили в оптимальные сроки в соответствии с требованием возделываемых культур.

Перед закладкой и в конце ротации севооборота в отобранных образцах почвы (слой 0-20 см) определялся $\mathrm{pH}$ солевое потенциометрически, гидролитическая кислотность по Каппену. Определение суммы поглощённых оснований проведено по Каппену-Гильковицу с последующим расчётом степени насыщенности почвы основаниями. Щелочногидролизуемый азот определяли по Корнфилду, общий фосфор - по Гинзбург, подвижный фосфор и калий по Чирикову, калий обменный - по Масловой, степень подвижности калия - в вытяжки $\mathrm{CaCl}_{2}$. При определении степени подвижности фосфора использовали метод Скофилда. Водопрочность почвенных агрегатов определяли в стоячей воде по Андрианову, в модификации Качинского.

Результаты исследования. Под действием внесенных удобрений в зернопропашном севообороте показатели плодородия черноземной почвы изменяются, и эти изменения отразились на балансе питательных элементов в севообороте.

Таблица 1 - Дозы минеральных удобрений (кг. д.в./га)

\begin{tabular}{|l|c|c|c|}
\hline \multicolumn{1}{|c|}{ Культура севооборота } & $\mathrm{N}_{1} \mathrm{P}_{1} \mathrm{~K}_{1}$ & $\mathrm{~N}_{2} \mathrm{P}_{2} \mathrm{~K}_{2}$ & $\mathrm{~N}_{3} \mathrm{P}_{3} \mathrm{~K}_{3}$ \\
\hline Занятый пар (горох-овсяная смесь) & 30 & 60 & 90 \\
\hline Озимая пшеница & 30 & 60 & 90 \\
\hline Сахарная свекла & 90 & 120 & 150 \\
\hline Ячмень & \multicolumn{2}{|c|}{ изучается последействие удобрений } \\
\hline Ср. севооборотная доза & $\mathrm{N}_{38} \mathrm{P}_{38} \mathrm{~K}_{38}$ & $\mathrm{~N}_{60} \mathrm{P}_{60} \mathrm{~K}_{60}$ & $\mathrm{~N}_{83} \mathrm{P}_{83} \mathrm{~K}_{83}$ \\
\hline
\end{tabular}


Таблица 2 - Влияние удобрений на физико-химические свойства чернозема типичного (конец 4-ой ротации, слой 0-20 см)

\begin{tabular}{|c|c|c|c|c|c|}
\hline \multirow[t]{2}{*}{$\begin{array}{l}\text { № } \\
\text { ח/ח }\end{array}$} & \multirow{2}{*}{$\begin{array}{c}\text { Вариант, доза } \\
\text { удобрений, кг/га } \\
\text { д. в., т/ га в год }\end{array}$} & \multirow{2}{*}{$\mathrm{pH}_{\mathrm{HCl}}$} & $\begin{array}{c}\text { Гидролитическая } \\
\text { кислотность }\end{array}$ & $\begin{array}{c}\text { Сумма поглощен- } \\
\text { ных оснований }\end{array}$ & \multirow{2}{*}{$\begin{array}{c}\text { Степень насыще- } \\
\text { ния почвы осно- } \\
\text { ваниями, \% }\end{array}$} \\
\hline & & & \multicolumn{2}{|c|}{ мГ-экв/100 г почвы } & \\
\hline 1 & $\mathrm{~N}_{0} \mathrm{P}_{0} \mathrm{~K}_{0}$ & 6,6 & 1,47 & 30,0 & 99,2 \\
\hline 2 & $\mathrm{~N}_{38} \mathrm{P}_{38} \mathrm{~K}_{38}$ & 6,3 & 1,90 & 30,2 & 94,1 \\
\hline 3 & $\mathrm{~N}_{60} \mathrm{P}_{60} \mathrm{~K}_{60}$ & 6,2 & 2,41 & 30,2 & 93,6 \\
\hline 4 & $\mathrm{~N}_{83} \mathrm{P}_{83} \mathrm{~K}_{83}$ & 5,4 & 4,79 & 27.8 & 85,3 \\
\hline 5 & Наво3 5 т/га & 6,4 & 2,41 & 33.1 & 93,2 \\
\hline 6 & Навоз 10 т/га & 6,2 & 2,50 & 32.7 & 92,9 \\
\hline 7 & Навоз 15 т/га & 6,5 & 1,76 & 33,7 & 95,0 \\
\hline 8 & $\begin{array}{l}\text { Наво3 } 5 \mathrm{~T} / \text { га } \\
+\mathrm{N}_{60} \mathrm{P}_{60} \mathrm{~K}_{30}\end{array}$ & 6,4 & 2,23 & 32,3 & 93,6 \\
\hline 9 & $\begin{array}{l}\text { Наво3 } 10 \mathrm{~T} / \text { га } \\
+\mathrm{N}_{60} \mathrm{P}_{60} \mathrm{~K}_{30}\end{array}$ & 6,2 & 2,41 & 31,2 & 92,8 \\
\hline 10 & $\begin{array}{l}\text { Навоз } 15 \mathrm{~T} / \text { га } \\
+\mathrm{N}_{60} \mathrm{P}_{60} \mathrm{~K}_{30}\end{array}$ & 6,0 & 2,83 & 31.0 & 97,4 \\
\hline
\end{tabular}

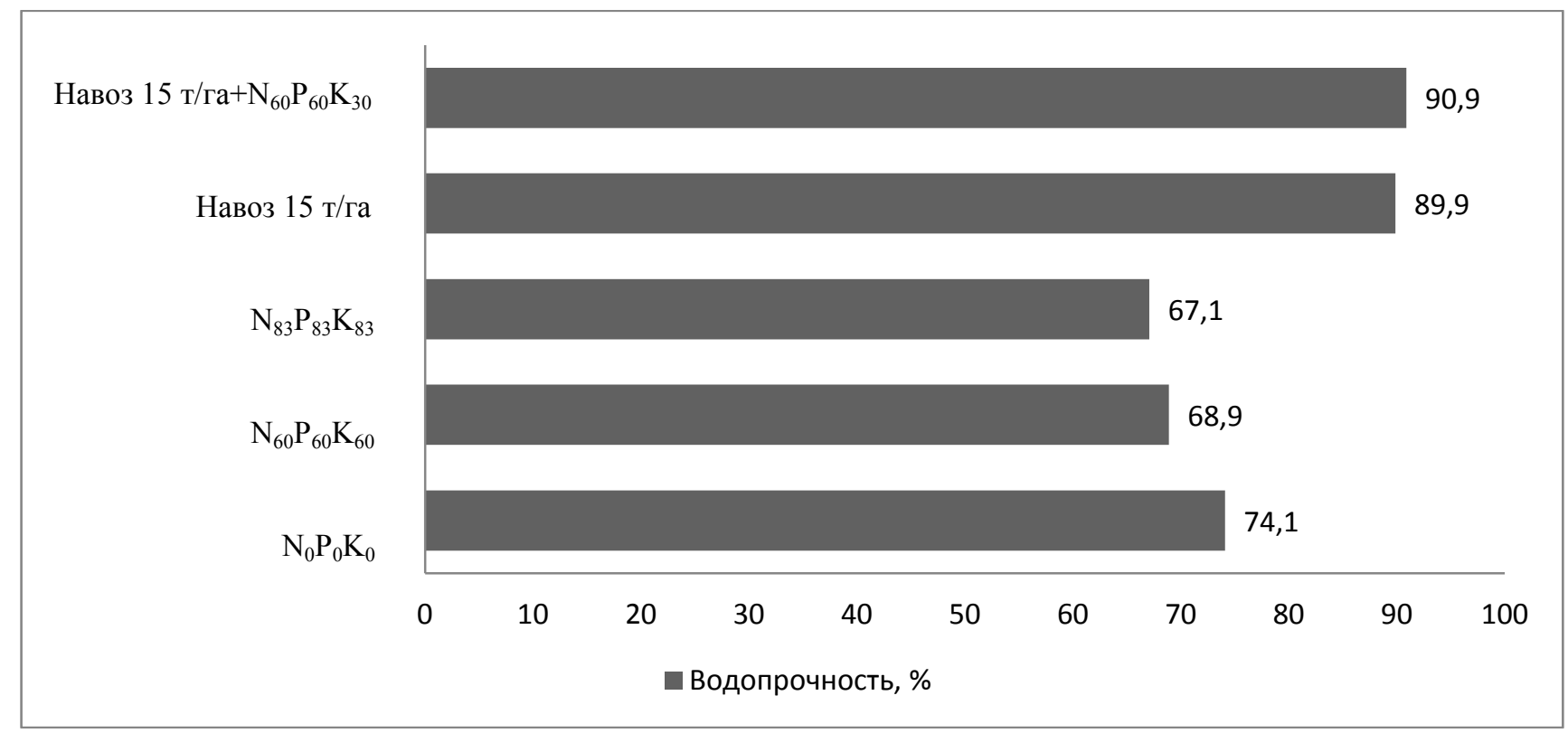

Рисунок 1 - Водопрочность почвенных агрегатов типичного чернозема в слое 0-20 см (по Андрианову)

Плодородие почв во многом определяется совокупностью физико-химических показателей. Представленные данные таблицы 2 показывают, что от постоянного применения минеральных удобрений в течение четырех ротаций зернопропашного севооборота в пахотном слое черноземной почвы идет медленное ухудшение физико-химических свойств, особенно на вариантах с минеральной системой удобрения. Так, с увеличением дозы минеральных удобрений с $\mathrm{N}_{38} \mathrm{P}_{38} \mathrm{~K}_{38}$ до $\mathrm{N}_{83} \mathrm{P}_{83} \mathrm{~K}_{83}$ кг/га в год гидролитическая кислотность увеличилась по сравнению с контролем с 1,47 до 4,79 мг-экв/100 г почвы, значение $\mathrm{pH}_{\mathrm{HCl}}$ понизилось с 6,6 до 5,4, степень насыщения почвы обменными основаниями ППК сократилась с 99,2 до 85,4 мг-экв/ 100 г почвы.

По-видимому, длительное насыщение зернопропашного севооборота минеральными удобрениями в дозе более $\mathrm{N}_{60} \mathrm{P}_{60} \mathrm{~K}_{60}$ кг/га в год ведет к нарушению кислотно-основного равновесия в почве и создает угрозу подкисления. При этом сумма поглощенных оснований практически не изменялась на всех вариантах опыта и составляла 27,9-33,1 мг- экв/100 г почвы, что указывает на высокую буферную способность чернозема типичного.

Произошедшие изменения физико-химических свойств чернозема типичного после прохождения четырех ротаций севооборота отразились на структурном состоянии почвы. Одним из показателей структурности пахотного слоя является его водопрочность, которая характеризует стойкость почвенных агрегатов к разрушению от дождевых потоков и механического воздействия техники. Анализ водопрочности почвенных агрегатов показал, что продолжительное использование в севообороте органических удобрений, а также их использование совместно с полным минеральным удобрением способствует повышению водопрочности по сравнению с вариантом без удобрений на 15,8-16,8 \% (рисунок 1). 
Таблица 3 - Влияние удобрений на агрохимические показатели плодородия почвы (конец 4-ой ротации, слой $0-20 \mathrm{cm)}$

\begin{tabular}{|c|c|c|c|c|c|c|c|c|}
\hline \multirow{4}{*}{$\begin{array}{c}\text { Вариант, доза } \\
\text { удобрений } \\
\text { кг/га д.в., } \\
\text { т/га в год }\end{array}$} & \multicolumn{4}{|c|}{ Фосфор } & \multicolumn{4}{|c|}{ Калий } \\
\hline & \multirow{2}{*}{ общий } & \multicolumn{2}{|c|}{ подвижный } & \multirow{3}{*}{$\begin{array}{c}\text { степень под- } \\
\text { вижности } \\
\text { мг/л }\end{array}$} & \multicolumn{2}{|c|}{ обменный } & \multirow{2}{*}{ подвижный } & \multirow{3}{*}{$\begin{array}{c}\text { степень под- } \\
\text { вижности } \\
\text { мг/л }\end{array}$} \\
\hline & & $\mathrm{A}$ & Б & & $\mathrm{A}$ & $\overline{5}$ & & \\
\hline & \multicolumn{3}{|c|}{ МГ-эКВ $/ 100$ г } & & \multicolumn{3}{|c|}{ МГ-ЭКВ/100 г } & \\
\hline $\mathrm{N}_{0} \mathrm{P}_{0} \mathrm{~K}_{0}$ & 153 & 8,0 & 9,5 & 0,017 & 17,7 & 14,2 & 10,4 & 4,1 \\
\hline $\mathrm{N}_{38} \mathrm{P}_{38} \mathrm{~K}_{38}$ & 148 & 9,7 & 12,5 & 0,071 & 17,2 & 15,3 & 9,9 & 3,6 \\
\hline $\mathrm{N}_{60} \mathrm{P}_{60} \mathrm{~K}_{60}$ & 157 & 9,2 & 13,8 & 0,085 & 17,4 & 16,9 & 10,6 & 3,8 \\
\hline $\mathrm{N}_{83} \mathrm{P}_{83} \mathrm{~K}_{83}$ & 160 & 7,8 & 17,5 & 0,220 & 17,0 & 16,9 & 11,4 & 4,5 \\
\hline Навоз 5 т/га & 157 & 8,2 & 12,3 & следы & 18,6 & 15,3 & 10,4 & 3,5 \\
\hline Навоз 10 т/га & 160 & 8,7 & 13,5 & следы & 19,8 & 17,6 & 12,3 & 3,9 \\
\hline Навоз 15 т/га & 163 & 9,1 & 13,8 & 0,137 & 19,2 & 17,7 & 12,5 & 4,4 \\
\hline $\begin{array}{l}\text { Наво3 } 5 \mathrm{~T} / \Gamma \text { a } \\
+\mathrm{N}_{60} \mathrm{P}_{60} \mathrm{~K}_{30}\end{array}$ & 171 & 9,5 & 20,1 & 0,196 & 19,8 & 18,9 & 14,0 & 5,4 \\
\hline $\begin{array}{l}\text { Навоз } 10 \mathrm{~T} / \text { га } \\
+\mathrm{N}_{60} \mathrm{P}_{60} \mathrm{~K}_{30} \\
\end{array}$ & 173 & 9,2 & 20,1 & 0,225 & 17,0 & 18,1 & 15,1 & 5,5 \\
\hline $\begin{array}{l}\text { Наво3 } 15 \mathrm{~T} / \text { га } \\
+\mathrm{N}_{60} \mathrm{P}_{60} \mathrm{~K}_{30}\end{array}$ & 169 & 9,5 & 20,6 & 0,281 & 17,6 & 18,6 & 13,5 & 5,3 \\
\hline
\end{tabular}

А - исходное содержание; Б - содержание элемента в конце 4-ой ротации

Использование в севообороте минеральной системы удобрения отрицательно сказалось на физикохимических свойствах чернозема типичного, и их действие разрушающе отразилось и на водопрочности почвенных агрегатов, которая, по сравнению с контролем, снизилась на 5,2-7,0\%.

Влияние различных видов удобрений на агрохимические параметры пахотного слоя почвы показаны в таблицы 3.

Представленные данные показывают, что после прохождения четырех ротаций севооборота под действием ежегодного насыщения его удобрениями, содержание в почве фосфора увеличивается.

Длительное применение в севообороте возрастающих доз минеральных и органических удобрений способствовало, к концу четвертой ротации, поднятию уровня обеспеченности почвы подвижным фосфором от среднего до повышенного, а на вариантах с внесением возрастающих доз навоза на минеральном фоне $\left(\mathrm{N}_{60} \mathrm{P}_{60} \mathrm{~K}_{30}\right)$ до высокого. Необходимо отметить, что при насыщении севооборота минеральными удобрениями (вариант $\left.\mathrm{N}_{83} \mathrm{P}_{83} \mathrm{~K}_{83}\right)$ и органическими удобрениями $(5,110$, 15 т/га в год) на минеральном фоне в пахотном слое почвы чернозема типичного наблюдается прогрессивный рост не только подвижного фосфора, но и существенно увеличилась степень его подвижности. На этих вариантах степень подвижности фосфора в почве достигла до 0,196-0,281 мг/л при 0,017 мг/л на контроле. Расчёты показали, что баланс фосфора на этих вариантах положительный с возвратом выноса удобрениями 112$164 \%$.

Баланс калия во все годы проведения опыта по всем вариантам был дефицитным, что сказалось на уменьшении в пахотном слое чернозема типичного содержания обменного калия. Стабилизация обменного калия в почве наступила при возврате с удобрениями $52 \%$ вносимого калия с удобрениями на варианте $\mathrm{N}_{83} \mathrm{P}_{83} \mathrm{~K}_{83}$. Процесс накопления обменного калия и увеличение степени его подвижности в почве наступил при возмещении выноса калия удобрениями на 60-80 \% на вариантах с органоминеральной системой удобрения. Такое положение указывает на то, что чернозем типичных нуждается в пополнении калия в почве за счет внесения на минеральном фоне органических удобрений.

Выводы. Ежегодное насыщение четырехпольного зернопропашного севооборота минеральными удобрениями сдвинуло физико-химические свойства пахотного слоя почвы в сторону подкисления, что негативно повлияло на водопрочность почвенных агрегатов, тогда как органическая и органо-минеральная системы удобрения значительно улучшили эти показатели.

Продолжительное применение в севообороте минеральных и органических удобрений способствовало, к концу четвертой ротации, поднять уровень обеспеченности почвы подвижным фосфором от среднего до повышенного, а на вариантах с внесением возрастающих доз навоза на минеральном фоне $\left(\mathrm{N}_{60} \mathrm{P}_{60} \mathrm{~K}_{30}\right)$ до высокого, что создало прогрессивный баланс фосфора в севообороте. При отрицательном балансе калия в севообороте накопления обменного калия и увеличение степени его подвижности в почве установилось на вариантах с органоминеральной системой удобрения при возмещении на 60-80 \% выноса калия удобрениями. 


\section{Список использованных источников}

1. Боева Н.Н. Влияние органических и минеральных удобрений на плодородие чернозема типичного и продуктивность озимой пшеницы (в условиях северо-западной части ЦЧЗ): дисс. ... на соиск. уч. ст. канд. с.х. наук, 2000. - 143 с.

2. Дериглазова Г.М., Айдиев А.Я. Особенности возделывания ярового ячменя на склоновых землях Центрального Черноземья. - Курск: ГНУ Курский НИИ АПП, 2013. - 233 с.

3. Дериглазова Г.М., Боева Н.Н. Улучшенный балансовый метод расчета доз минеральных удобрений для эффективного использования природного потенциала агроландшафтов // Вестник Курской сельскохозяйственной академии. - 2018. - № 7. - С. 11-14.

4. Плодородие черноземов России / Под. ред. Н.Г. Милащенко. - М.: Агроконсалт, 1998. - 688 с.

5. Долгополова Н.В. Факторы плодородия в биологическом земледелии лесостепи Центрального Черноземья // Региональный вестник. - 2016. - № 2(3). - С. 27-29.

6. Долгополова Н.В. Биологическая система земледелия и воспроизводство плодородия почвы в лесостепи Центрального Черноземья // Региональный вестник. - 2016. - № 2(3). - С. 29-32.

7. Эффективное использование природных ресурсов Курской области / И.Я. Пигорев, Е.Е. Сивак, С.Н. Волкова, М.В. Гейко // Вестник Курской государственной сельскохозяйственной академии. -2014. - № 3. - C. 52-53.

8. Ecosystems' monitoring with purpose for phage detection of pathogen Microorganisms as Part of Agricultural Foresight / E.N. Kovaleva, D.A. Vasilyev, S.A. Plygun et al. // Advances in Environmental Biology. 2016. - T. 10. - № 3. - С. 1-3.

9. Пигорев И.Я., Ишков И.В. Улучшение агроэкологического состояния почв как способ повышения продуктивности полевых культур // Аграрная наука - сельскому хозяйству: сб. статей: в 3 книгах. - Барнаул: Алтайский ГАУ, 2017. - С. 236-238.

\section{List of used sources}

1. Boeva N.N. The influence of organic and mineral fertilizers on the fertility of typical Chernozem and the productivity of winter wheat (under the conditions of the northwestern part of the Central Black Sea Plant): diss. ... on the competition uch. Art. Cand. S.-H. Sciences, 2000. - 143 p.

2. Deriglazova G.M., Aidiev A.Ya. Features of spring barley cultivation on the slope lands of the Central Black Soil Region. - Kursk: State Scientific Institution, Kursk Research Institute of App, 2013. - 233 p.

3. Deriglazova G.M., Boeva N.N. Improved balance method for calculating doses of mineral fertilizers for the effective use of the natural potential of agrolandscapes // West nick of the Kursk Agricultural Academy. 2018. - № 7. P. 11-14.

4. Fertility of Russian Black Soil / Under. ed. N.G. Milashchenko. - M.: Agrokonsalt, 1998. - 688 p.

5. Dolgopolova N.V. Fertility factors in biological agriculture of the forest-steppe of the Central Chernozem Region // Regional Bulletin. - 2016. - № 2 (3). - P. 27-29.

6. Dolgopolova N.V. Biological system of agriculture and the reproduction of soil fertility in the forest-steppe of the Central Chernozem Region // Regional Bulletin. - 2016. - № 2 (3). - Pp. 29-32.

7. The Efficiency of use of natural resources in Kursk Region / I.Y. Pigorev, E.E. Sivak, S.N. Volkova, M.V. Geiko // Bulletin of Kursk State Agricultural Academy. - 2014. - №. 3. - P. 52-53.

8. Ecosystems' monitoring with purpose for phage detection of pathogen Microorganisms as Part of Agricultural Foresight / E.N. Kovaleva, D.A. Vasilyev, S.A. Plygun et al. // Advances in Environmental Biology. 2016. - T. 10. - № 3. - C. 1-3.

9. Pigorev I.Y., Ishkov I.V. Improving the agro-ecological state of the soil as a way to increase the productivity of field crops // Agrarian science - agriculture: Coll. articles: in 3 books. - Barnaul: Altai State Agrarian University, 2017. - P. 236-238. 